\title{
Constitutional Crisis in Poland 2015-2016 in the Light of the Rule of Law Principle
}

\author{
Marcin Wiącek
}

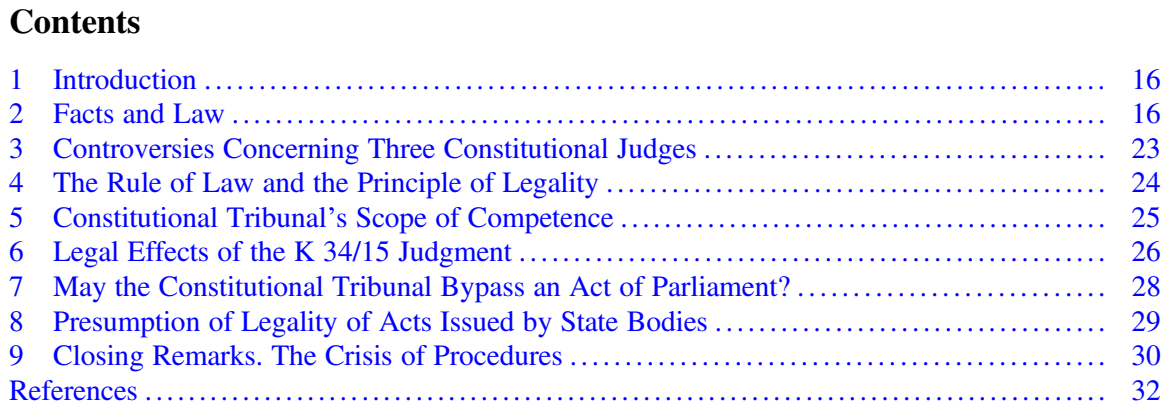

\begin{abstract}
This chapter concerns the constitutional crisis in Poland that began in 2015. It was triggered by appointing judges of the Constitutional Tribunal, by the outgoing Parliament, and then by re-appointing new judges for the same vacancies. Thus, the status of three judges elected by the previous Parliament and three judges elected by the current Parliament remains disputable.

One of the crucial elements of the rule of law is the principle of legality. There are two aspects of this principle: the presumption of legality that covers all acts of state bodies; the revoking of this presumption may be performed only within procedures prescribed by the law. The law should indicate a state body competent to revoke the presumption of legality and define the legal effects of such revoking. If the law is incomplete, incoherent or imprecise in that scope-that may lead to legal and political crisis. Polish legislation and Constitution fail to comply with the said standard. This is one of the causes of the constitutional crisis in Poland.

In a state governed by the rule of law state bodies should mutually respect their acts. State bodies should not treat acts or decisions issued by other state bodies as invalid or non-existent, unless it is declared within a procedure prescribed by the law. Otherwise, a legal chaos may occur. Courts are not empowered to evaluate the
\end{abstract}

\footnotetext{
M. Wiącek (四)

Faculty of Law and Administration, University of Warsaw, Warszawa, Poland
} 
lawfulness of the Tribunal's judgments. One of the crucial elements of the rule of law principle is the certainty of law.

\section{Introduction}

This contribution concerns the crisis that was caused by the election of five judges of the Polish Constitutional Tribunal (CT) in October and December 2015. The events that took place at that time led to the greatest constitutional dispute in the modern history of Poland and to the so-called 'rule of law crisis' in Poland that was subject to numerous procedures, in particular, before the organs of the European Union and the Council of Europe. ${ }^{1}$ The principal aim of this contribution is to explain and evaluate sine studio et ira the sequence of actions that led to the crisis and to identify its root causes from the perspective of the rule of law principle.

It should be emphasised that the precise analysis of the aforementioned question is crucial, since the whole rule of law crisis in Poland began with the Constitutional Tribunal-related problem. ${ }^{2}$

\section{Facts and Law}

The constitutional crisis in Poland began in October 2015. It was triggered by appointing, by the outgoing Parliament (elected for the 2011-2015 term of office), five new judges of the CT. Subsequently, in December 2015, after parliamentary elections, the newly-elected Sejm re-appointed constitutional judges for the same vacancies. ${ }^{3}$

According to Art. 194 para. 1 of the Polish Constitution: 'The Constitutional Tribunal shall be composed of 15 judges chosen individually by the Sejm for a term

\footnotetext{
${ }^{1}$ See, in particular, Opinion no. 833/2015 of the Venice Commission on Amendments to the Act of 25 June 2015 on the Constitutional Tribunal of Poland; Opinion no. 860/2016 of the Venice Commission on the Act on the Constitutional Tribunal; Commission Recommendation (EU) 2016/1374 of 27 July 2016 regarding the rule of law in Poland; Commission Recommendation (EU) 2017/146 of 21 December 2016 regarding the rule of law in Poland complementary to Commission Recommendation (EU) 2016/1374.

${ }^{2}$ Cf. Sadurski (2019), pp. 15-16.

${ }^{3}$ Detailed information, concerning subsequent stages of the constitutional crisis in Poland 2015-2016, is presented, in particular, in the following publications: Kustra (2016), Szuleka et al. (2016), Krzywoń (2018) and Sadurski (2019).

${ }^{4}$ Constitution of the Republic of Poland, adopted by the National Assembly on 2 April 1997 (English translation: www.sejm.gov.pl/prawo/konst/angielski/kon1.htm [accessed 19 August 2019]).
} 
of office of 9 years from amongst persons distinguished by their knowledge of the law. No person may be chosen for more than one term of office. ${ }^{5}$ On the basis of this constitutional provision, in 2006, five constitutional judges were appointed. Their terms of office began on 6 November (three judges), on 2 December (one judge) and on 8 December 2006 (one judge). Thus, five vacancies opened 9 years later, accordingly, on 7 November, on 3 December and on 9 December 2015.

On 25 June 2015, a few months prior to parliamentary elections, the Parliament adopted the new CT Act (2015 Act) which repealed the hitherto binding CT Act 1997. ${ }^{6}$ The principal aim of the new Act was to simplify the procedure for the constitutional review, to accelerate this procedure and to explain certain procedural doubts that had arisen in the past.

The Sejm decided, however, that the 2015 Act should comprise also some transitional provisions which would concern the election procedure for the vacancies that would open on November and December 2015. According to Art. 137 of the 2015 Act: 'With regard to judges of the Tribunal whose terms of office end in 2015, the time-limit for submitting the proposal referred to in Art. 19 para. 2 shall be 30 days from the date of entry into force of the Act. ${ }^{, 7}$

On 21 July 2015, the then Polish President signed the new CT Act. On 30 July 2015 it was published in the Journal of Laws and it entered into force after the expiry of a 1-month vacatio legis period. ${ }^{8}$ In the meantime, i.e. on 17 July 2015, the President summoned the parliamentary elections. The day of elections was set for 25 October 2015.

During the last session of the outgoing Sejm, the Deputies decided to elect five new constitutional judges. Five Sejm's resolutions on appointing judges were adopted on 8 October 2015, i.e. 17 days before the parliamentary elections. Each resolution indicated the exact date when the term of office of a newly-elected judge would commence. Three of them indicated 7 November (R. Hauser, A. Jakubecki, K. Ślebzak), one-3 December (B. Sitek) and one-9 December 2015 (A. Sokala).

According to Art. 21 para. 1 of the 2015 Act, a person elected by the Sejm to assume the office of a constitutional judge was subsequently obliged to take the oath of office in the presence of the Polish President. ${ }^{9}$ As regards persons elected on 8 October 2015, the President did not, however, organize the swearing-in ceremony.

\footnotetext{
${ }^{5}$ Sejm is the first chamber of the Polish Parliament.

${ }^{6}$ English translations of the 1997 Act and the 2015 Act: www.trybunal.gov.pl/en/about-the-tribunal/ legal-basis/the-constitutional-tribunal-act/archive/ (accessed 19 August 2019).

${ }^{7}$ Art. 19 para. 2 of the 2015 Act: 'A proposal of a candidate for the judgeship at the Tribunal shall be lodged with the Marshal of the Sejm no later than 3 months prior to the end of the term of office of a judge of the Tribunal.'

${ }^{8}$ See Art. 139 of the 2015 Act.

${ }^{9}$ According to Art. 21 para. 2 of the 2015 Act: 'Refusal to take the oath of office shall be tantamount to resignation from the office of a judge of the Tribunal.'
} 
Parliamentary elections were held on 25 October 2015. The term of office of the newly-elected Sejm began on 12 November 2015, according to the order of the Polish President, issued on 5 November 2015. ${ }^{10}$

Immediately after the inauguration of the new Sejm's term of office, on 17 November 2015, a group of Sejm Deputies lodged with the CT a motion to review the constitutionality of Art. 137 and some other provisions of the 2015 Act, in particular provisions concerning the swearing-in stage of a constitutional judge nomination procedure. Two days after having received the motion, the CT announced that the hearing of the case would be carried out 2 weeks later, i.e. on 3 December 2015.

A few days before the hearing, on 25 November 2015, the Sejm adopted five resolutions declaring that the elections of constitutional judges, performed by the previous Sejm on 8 October 2015, had been null and void due to procedural irregularities. In the reasoning for these resolutions their authors (a group of Sejm Deputies) acknowledged that the Sejm was not empowered to dismiss a constitutional judge from office, once he/she had been lawfully elected. The Sejm was, however, authorized to proclaim - merely in the form of a declaration, as opposed to a law-making decision-that a resolution on appointing a constitutional judge had been adopted in breach of law and thus it had been invalid from the very beginning. The authors of the November 2015 resolutions argued that, notwithstanding the transitional provisions of the 2015 Act, the resolutions of 8 October 2015 had contravened the Sejm's Rules of Procedure (Standing Orders). ${ }^{11}$ For that reason, the majority of the Deputies expressed the opinion that the said resolutions had not brought about any legal effects and, consequently, there were still five judicial vacancies opened at the $\mathrm{CT}$.

Three days before hearing the case, on 30 November 2015, the CT issued a decision on temporary (interim) injunction. The Tribunal called upon the Sejm not to appoint new judges until pronouncing a judgment on constitutionality of the 2015 Act (i.e. until 3 December 2015). It should be pointed out that the temporary injunction was not directly based on the 2015 Act, since this Act did not explicitly empower the Tribunal to issue such injunctions, unless the procedure was initiated by an individual's constitutional complaint (referred to in Art. 79 of the Constitution). The Tribunal explained, however, that legal bases for the injunction have been

\footnotetext{
${ }^{10}$ According to Art. 98 para. 1 of the Constitution: 'The Sejm and the Senate shall be chosen each for a 4-year term of office. The term of office of the Sejm and Senate shall begin on the day on which the Sejm assembles for its first sitting and shall continue until the day preceding the assembly of the Sejm of the succeeding term of office.' According to Art. 109 para. 2 of the Constitution: 'The first sitting of the Sejm and Senate shall be summoned by the President of the Republic to be held on a day within 30 days following the day of the elections (...).'

${ }^{11}$ The Deputies argued that, on the day of the elections of constitutional judges by the previous Sejm, Art. 137 of the 2015 Act had been contrary to Art. 30 para. 3(1) of the Sejm's Rules of Procedure according to which a candidature for the office of a constitutional judge shall be presented to the Marshall of the Sejm 30 days before the expiry of a constitutional judge mandate. That lack of coherence between Art. 137 of the 2015 Act and Art. 30 para. 3 subpara. 1 of the Sejm's Rules of Procedure led to the invalidity of the resolutions of 8 October 2015.
} 
found in the Civil Procedure Code 1964 which was applicable, mutatis mutandis, to the procedure before the Tribunal in matters not regulated within the 2015 Act. ${ }^{12}$

The Sejm decided not to follow the temporary injunction. On 2 December 2015 (a day before the CT judgment) the Sejm elected five persons for the offices of constitutional judges (H. Cioch, L. Morawski, M. Muszyński, J. Przyłębska, P. Pszczółkowski). They have been forthwith sworn by the Polish President. ${ }^{13}$

Next day, on 3 December 2015, the Tribunal issued the judgment (ref. no. K 34/15). ${ }^{14}$ In the operative part of the judgment the Tribunal ruled, inter alia, that Art. 137 of the 2015 Act, insofar as it concerned three judges whose terms of office ended on 6 November 2015, was consistent with the Constitution and, insofar as it concerned two judges whose terms of office either ended on 2 December 2015 or would end on 8 December 2015, violated the Constitution. Furthermore, the Tribunal ruled that the Polish President was, in general, devoid of the power to deny giving the oath of office to a person elected by the Sejm for the office of a constitutional judge. In the reasoning part of its judgment, the CT expressed the viewpoint that three judges had been lawfully elected by the previous Sejm and, therefore, the President was still under obligation to give them the oath of office. The Tribunal was of the opinion that the appointment of two other judges lay within the scope of competence of the newly-elected Sejm and, therefore, the previous Sejm had not been constitutionally empowered to fill in these two vacancies 'in advance. ${ }^{15}$

One day after the Tribunal had delivered the aforementioned judgment, a group of Sejm Deputies lodged with the Tribunal a motion to review five Sejm's resolutions of 25 November 2015 (declaring that the appointments performed by the previous Sejm had been invalid) and five resolutions of 2 December 2015 (on appointing new constitutional judges). These motions were not, however, adjudicated to their merits. On 7 January 2016, the CT discontinued proceedings (ref. no. U 8/15), since according to the majority of judges the Tribunal was not constitutionally authorized to review the aforementioned resolutions.

Subsequently, the then CT President A. Rzepliński expressed an opinion that, as a result of the K 34/15 judgment, three judges elected by the previous Sejm for the

\footnotetext{
${ }^{12}$ See Art. 74 of the 2015 Act. In its hitherto jurisprudence the CT had always rejected motions to issue temporary injunctions in proceedings initiated by a group of Sejm Deputies, due to the lack of legal basis to issue such injunctions (see e.g. the decision of 11 May 2004, ref. no. K 15/04; English summary: www.trybunal.gov.pl/fileadmin/content/omowienia/K_15_04_pp_GB.pdf [accessed 19 August 2019]).

${ }^{13}$ Four judges were sworn on 3 December 2015, prior to the opening of the hearing before the CT. Judge J. Przyłębska was sworn on 9 December 2015, since she had been appointed for the term of office which would inaugurate on this day.

${ }^{14}$ English translation: www.trybunal.gov.pl/en/hearings/judgments/art/8748-ustawa-o-trybunalekonstytucyjnym (accessed 19 August 2019).

${ }^{15}$ See also the similar judgment of 9 December 2015, ref. no. K 35/15 (English translation: www. trybunal.gov.p1/en/hearings/judgments/art/8792-nowelizacja-ustawy-o-trybunale-konstytucyjnym [accessed 19 August 2019]).
} 
terms of office beginning on 7 November 2015 (R. Hauser, A. Jakubecki, K. Ślebzak) were still expecting to be sworn by the Polish President. In consequence, the CT President allowed only two judges, from amongst five persons elected by the new Sejm and sworn by the Polish President, to perform their judicial duties, i.e. judges elected for the terms of office beginning on 3 December and 9 December 2015 (P. Pszczółkowski, J. Przyłębska). The CT President denied assigning cases to three other judges elected by the new Sejm (H. Cioch, L. Morawski, M. Muszyński). The CT President did, however, make it possible for these persons to work at the Tribunal, as its employees. They obtained their own office rooms and their judicial salary has been paid every month.

As a result of the aforementioned facts, the CT was composed of 12 judges allowed by the CT President to perform their judicial duties. Three remaining judgeships have become disputable, since, on one hand, the Polish President did not give the oath of office to three persons elected by the previous Sejm and, on the other hand, the CT President did not allow three persons elected by the new Sejm to perform their judicial duties.

In the meantime, on 22 December 2015, the Parliament adopted the Amendment Act, modifying the 2015 Act (Amendment Act). It envisaged, inter alia, that the CT should have adjudicated most of the cases sitting in a plenary session composed of at least 13 judges. It also imposed upon the CT the obligation to adjudicate cases in accordance with the order in which the motions were received by the Tribunal. Furthermore, the Tribunal's judgments, issued by the full bench, were to be adopted by the qualified majority of $2 / 3$ votes. The Amendment Act entered into force upon the day of its publication (on 28 November 2015), without any vacatio legis period.

After its entry into force, the Amendment Act was immediately challenged before the Tribunal by two groups of Sejm Deputies, the First President of the Supreme Court, the National Council of the Judiciary and by the Ombudsman. The Tribunal decided to bypass some of the Amendment Act's provisions and to rule upon its conformity with the Constitution sitting in a panel composed of 12 judges, i.e. ten judges appointed prior to parliamentary elections and two judges appointed by the new Sejm, who had been allowed to perform their judicial duties by the CT President. The judgment was issued on 9 March 2016 (ref. no. K 47/15). ${ }^{16}$ The Tribunal ruled that the whole Amendment Act was unconstitutional and the Act failed to bring about any legal consequences, in particular it did not effectively modify the original version of the 2015 Act. The majority of judges decided to proceed the case directly on the basis of the Constitution. These judges were of the opinion that Art. 8 para. 2 and Art. 195 para. 1 of the Constitution ${ }^{17}$ empowered the Tribunal to deny applying provisions of the Act of Parliament. Hence, the CT

\footnotetext{
${ }^{16}$ English translation: www.konstytucja.wpia.uw.edu.pl/wp-content/uploads/2017/05/Judgmentof-the-Polish-Constitutional-Tribunal_ref.-no.-K_47_15_en.pdf (accessed 19 August 2019).

${ }^{17}$ Art. 8 para. 2 of the Constitution: 'The provisions of the Constitution shall apply directly, unless the Constitution provides otherwise.' Art. 195 para. 1 of the Constitution: 'Judges of the Constitutional Tribunal, in the exercise of their office, shall be independent and subject only to the Constitution.'
} 
disregarded, inter alia, the provision pursuant to which the full bench of the CT should have been composed of at least 13 judges.

On 9 March 2016, the K 47/15 judgment was verbally announced in the courtroom and, subsequently, its operative part, signed by 12 judges, ${ }^{18}$ was delivered to the Chancellery of the Prime Minister for official publication in the Journal of Laws. It should be pointed out that according to Art. 190 para. 2 of the Constitution: 'Judgments of the Constitutional Tribunal (...) shall be required to be immediately published in the official publication in which the original normative act was promulgated (...).' Art. 190 para. 3 of the Constitution stipulates that 'A judgment of the Constitutional Tribunal shall take effect from the day of its publication (...).' The duty to publish the Journal of Laws is vested in the Chancellery of the Prime Minister.

The Prime Minister's Chancellery expressed the opinion that the K 47/15 judgment was null and void, since it had been delivered by the 12 -judge panel, as opposed to the panel composed of at least 13 judges, as it had been required by the Amendment Act which, during the Tribunal's session, had been in force and had enjoyed the presumption of constitutionality. Therefore, the judgment was not perceived by the Prime Minister as a CT's decision, but rather as a non-binding opinion of the majority of constitutional judges. For this reason, the Prime Minister's Chancellery denied publishing the judgment. However, according to the majority of the constitutional judges, the act delivered on 9 March 2016 was indeed the CT's judgment, its verbal announcement resulted in the revoking of the Amendment Act's presumption of constitutionality and, therefore, this Act may not be applied in the future.

From that moment, the Tribunal continued its routine adjudicating work, but the Prime Minister's Chancellery refused to publish its judgments in the Journal of Laws. It stemmed from the fact that the Tribunal respected the $\mathrm{K} 47 / 15$ judgment and went on proceeding on the basis of the 2015 Act in its original wording. The Prime Minister's Chancellery was of the opinion that the K 47/15 judgment had not brought about any legal effects. Therefore, in the Chancellery's opinion, the Amendment Act was still in force and decisions issued in breach thereof may not be treated as CT's judgments.

On 22 July 2016, the Parliament adopted the new CT Act, repealing the 2015 Act. The new Act obliged the Prime Minister to publish all CT's judgments issued 'in breach of the 2015 Act,' except for the K 47/15 judgment. The situation became more complex after the Tribunal, several days before the Act of 22 July 2016 entered into force, had ruled that some of this Act's provisions had been unconstitutional (judgment of 11 August 2016, ref. no. K 39/16). That judgment has not been published either, since the procedure within which it was issued ignored the

\footnotetext{
${ }^{18}$ Two newly-elected judges (J. Przyłębska, P. Pszczółkowski) presented dissenting opinions. They expressed the viewpoint that the CT was not empowered to bypass the Amendment Act, even when reviewing its conformity with the Constitution, and that three remaining persons, who had been elected to be the CT judges in December 2015 (H. Cioch, L. Morawski, M. Muszyński), should have been allowed by the CT President to participate in the adjudication of the K 47/15 case.
} 
Amendment Act of 22 December 2015. Therefore, not only the K 39/16 judgment, but also other CT's decisions pronounced after that judgment were denied being published. ${ }^{19}$

On 30 November and 13 December 2016, three new Acts concerning the CT, the status of its judges and transitional provisions were issued by the Parliament, signed by the President and entered into force. ${ }^{20}$ On 19 December 2016, the term of office of the hitherto CT President expired. Two days later the Polish President nominated a new CT President (judge J. Przyłębska). ${ }^{21}$

The newly-appointed CT President allowed the three judges elected on 2 December 2015, who had not been hitherto assigned cases by the previous Tribunal's President (H. Cioch, L. Morawski, M. Muszyński), to perform their judicial duties. Furthermore, the CT President ordered the publication of the hitherto unpublished judgments (except for the K 47/15, K 39/16 and K 44/16 judgments). ${ }^{22}$ These CT President's orders were based on transitional provisions contained within the Act of 13 December $2016 .{ }^{23}$ The aforementioned three judgments were also removed from the official collection of the CT's rulings. ${ }^{24}$ Eventually, the aforementioned three judgments were officially published in $2018 .^{25}$

\footnotetext{
${ }^{19}$ For more details, see Sadurski (2019), pp. 75 et seq.

${ }^{20}$ English translations: www.trybunal.gov.pl/en/about-the-tribunal/legal-basis/the-constitutionaltribunal-act (accessed 1 March 2018).

${ }^{21}$ According to Art. 194 para. 2 of the Constitution: 'The President and Vice-President of the Constitutional Tribunal shall be appointed by the President of the Republic from amongst candidates proposed by the General Assembly of the Judges of the Constitutional Tribunal.' The procedure of proposing candidates for the position of new CT President provoked certain legal doubts as to whether the General Assembly lawfully presented candidatures to the President. These doubts stemmed from the fact that, on 20 December 2016, during the sitting of the General Assembly, only six judges did cast their votes, eight judges denied voting and one judge was on leave. The procedure was based on a special transitional provision (Art. 21 of the Act of 13 December 2016). On one hand, this provision envisaged that candidatures should have been presented 'by resolution' of the General Assembly. On the other hand, it did not require any particular quorum that should have been reached in order to adopt resolutions. That problem has been presented before the Supreme Court by the Warsaw Court of Appeal's referral. The Supreme Court, however, refused to rule the case to its merits (decision of 12 September 2017, ref. no. III SZP 2/17).

${ }^{22}$ The judgment K 44/16, issued on 7 November 2016, concerned the procedure for electing candidates for the positions of the President and the Vice-President of the Tribunal.

${ }^{23}$ According to Art. 18 para. 2 of the Act of 13 December 2016 (containing the transitional provisions), a person performing the duties of the CT President 'shall (...) assign cases to the judges of the Tribunal who have taken the oath of office before the President of the Republic of Poland and create conditions that make it possible for the judges of the Tribunal to perform their judicial duties.' The special basis for publishing judgments which had been issued 'in breach of' CT Acts of 2015 or 2016 had been created in Art. 19 of the said Act.

${ }^{24}$ It is published in the electronic form by the CT (see Art. 115 of the Act of 30 November 2016 on the Organization of the CT and the Mode of Proceedings before the CT).

${ }^{25}$ The specific legal basis for these publications was created by the Amendment Act of 12 April 2018. For more details, see Sadurski (2019), p. 78.
} 


\section{Controversies Concerning Three Constitutional Judges}

From the moment when the new CT President assumed her office, the Tribunal started to continue its routine adjudicating work being composed of 15 judges. However, some constitutional judges, participants to procedures, scholars and publicists express the opinion that the Tribunal's composition is contrary to law, since three mandates at the Tribunal are not exercised by legally-appointed persons. Judges holding these mandates are sometimes even called 'anti-judges' or 'body doubles'.

Some argue that judgments issued with the participation of at least one of the aforementioned three persons are illegal and invalid. For instance, in his dissenting opinion attached to the CT judgment of 4 April 2017 (ref. no. P 56/14), judge $\mathrm{S}$. Rymar stated that one of judges of the adjudicating panel (H. Cioch) was not a constitutional judge, since he had been elected by the Sejm for the judgeship that had been already occupied by a person appointed by the previous Sejm. Therefore, in judge Rymar's opinion, the P 56/14 judgment has been invalid, since it was delivered with the participation of a person who was not legally capable to perform his judicial duties. ${ }^{26}$

On the other hand, arguments are being raised that, currently, the Tribunal is lawfully-composed, since due to the law violations committed by the previous Parliament, the new Sejm was empowered to fill in all five vacancies at the Tribunal. For instance, in the reasoning for one of its latest decisions, i.e. the judgment of 24 October 2017, ref. no. K 10/17, the CT, sitting as a 5-judge panel, expressed the opinion that it was a misunderstanding to argue that the legal status of three constitutional judges had been determined by hitherto-delivered CT's judgments. In particular, the K 34/15 judgment concerned merely the constitutionality of Art. 137 of the 2015 Act which regulated nothing more than time-limits for submitting candidatures for the offices of a constitutional judge. As regards the Sejm's resolutions on appointing constitutional judges, the Tribunal declared, in the U 8/15 decision, that it was not constitutionally authorized to perform the review of such acts. In conclusion of the K 10/17 judgment, the Tribunal stated that the K 34/15 judgment's entry into force did not affect the legality of any of five appointments performed by the new Sejm on 2 December $2015 .^{27}$ The detailed analysis of this complicated constitutional problem will be performed hereinafter (in point 6 below).

\footnotetext{
${ }^{26}$ See also dissenting opinions attached to the following CT's decisions: judgment of 16 March 2017, ref. no. Kp 1/17 (judges L. Kieres, M. Pyziak-Szafnicka, S. Wronkowska-Jaśkiewicz); procedural decisions of 20 April 2017, ref. no. K 23/15, of 16 May 2017, ref. no. P 115/15, and of 11 October 2017, ref. no. K 14/16 (judge P. Tuleja); judgment of 24 October 2017, ref. no. K $1 / 17$ (judge L. Kieres).

${ }^{27}$ See also: CT's procedural decisions of 15 February 2017, ref. no. K 2/15, and of 19 April 2017, ref. no. K 10/15; Muszyński (2017), pp. 127 et seq.
} 


\section{The Rule of Law and the Principle of Legality}

The rule of law principle, enshrined in Art. 2 of the Constitution and in Art. 2 of the Treaty on the European Union, is a very broad concept and the source of several detailed principles. ${ }^{28}$ One of the crucial elements of the rule of law is the principle of legality which, in general, means that all state bodies should act on the basis and within the limits of the law (see also Art. 7 of the Constitution). The discussion on the constitutional crisis in Poland should take into account the fact that there are two specific aspects of the principle of legality:

Firstly, it is the presumption of legality that covers all acts of public power, namely Acts of Parliament, courts judgments, administrative decisions, acts of the President etc. In general, all acts of public powers should be presumed legal and valid. $^{29}$

Secondly, the presumption of legality may be challenged and then revoked. It is obvious that, on one hand, the violation of law by state bodies, or the abuse of powers, should not take place, but, on the other hand, it is not per se anything unusual in a state governed by the rule of law that such situations may occur. In the light of the rule of law principle, the revoking of the presumption of legality may, however, be performed only within procedures prescribed by the law. The law should, in particular, precisely indicate a state body competent to revoke the presumption of legality and define the legal effects of such revoking. Should the law be incomplete, incoherent or imprecise in that scope-that may lead to legal and political crisis.

Against that background, I express an opinion that Polish legislation and Constitution fail to comply with the aforementioned standard. The legality of state bodies' activity, which is the element of the rule of law principle, is not sufficiently safeguarded by appropriate procedural provisions of Polish law. That is one of the root causes of the crisis concerning the Polish CT. The Constitution and legislation fail to provide for exhaustive and sufficiently precise procedures within which certain essential legal disputes might be resolved. Therefore, as regards certain legal acts (e.g. constitutional judges' appointments, judgments of the CT), there is no procedural way to finally revoke or confirm their presumption of legality in case of a dispute.

\footnotetext{
${ }^{28} \mathrm{See}$, on the conceptual vagueness of the rule of law principle, e.g. Bárd (2016), pp. 190 et seq. See also Taborowski (2019), pp. 59 et seq.

${ }^{29}$ The concept of the presumption of legality may be found, in particular, in the ECJ case-law, cf. ECJ, Case 101/78 ECR 1979, 38 paras. 4-5; see also General Court Case T 471/11 ECLI EU T 2014, 739 para 117.
} 


\section{Constitutional Tribunal's Scope of Competence}

The main source of the constitutional crisis were controversies concerning the legality of the Sejm's resolutions, issued on 8 October 2015, on electing new constitutional judges. They have not been sworn by the President, and, after the parliamentary elections, the Sejm declared aforementioned resolutions to be legallyineffective (resolutions of 25 November 2015) and, consequently, appointed five new constitutional judges (resolutions of 2 December 2015).

One may pose a question whether there is an independent state body which would be legally capable to review the legality and constitutionality of the aforementioned Sejm's resolutions. The answer is 'no', since the Polish Constitution empowers neither the CT, nor any other judicial body, with the competence to examine the legality of the Sejm's individual resolutions, i.e. resolutions on personal nominations. In general, the CT may examine only statutes (Acts of Parliament), international agreements and legal provisions issued by central state bodies. ${ }^{30}$ In consequence, certain Sejm's resolutions are reviewable in the proceedings before the Tribunal, but that refers only to so-called 'normative' resolutions, i.e. resolutions that are the source of general and abstract legal norms. ${ }^{31}$ For that reason, in the aforementioned procedural decision of 7 January 2016 (ref. no. U 8/15), the Tribunal ruled that it was deprived of the power to review the Sejm's resolutions on appointing constitutional judges.

The Polish Constitution failed to introduce any systemic mechanism enabling constitutional review of state bodies' acts of applying the law, in particular acts issued by the Parliamentary Chambers. ${ }^{32}$ Perhaps the situation would be different, should the Polish Constitution expressly empower the Tribunal to review all acts enacted by the Parliament, notwithstanding their contents, like it is, for instance, in Lithuania. ${ }^{33}$ In particular, in 2005 the Lithuanian Constitutional Court ruled that the parliamentary resolution on the appointment of a constitutional judge was consistent with the Constitution. ${ }^{34}$ Another good example is Spain. The Spanish Constitutional Court is explicitly authorized to control the appointments of constitutional judges. ${ }^{35}$ Possibly, should the Polish CT have a similar scope of competence, the

\footnotetext{
${ }^{30}$ See Art. 188 para. $1-3$ of the Constitution.

${ }^{31}$ E.g. the CT found itself to be authorized to examine some provisions of the Sejm's resolution on appointing an investigative committee (see the judgment of 22 September 2006, ref. no. U 4/06; English translation: www.trybunal.gov.pl/en/case-list/judicial-decisions/art/5888-zakres-dzialaniatzw-bankowej-komisji-sledczej [accessed 19 August 2019]; see also Wiącek (2007), pp. 193 et seq. ${ }^{32}$ Cf. Brzozowski (2017), p. 20.

${ }^{33}$ See Art. 102 of the Lithuanian Constitution 1992.

${ }^{34}$ Judgment of 2 June 2005, ref. no. 10/05 (English translation: www.lrkt.lt/en/court-acts/search/ 170/ta924/content [accessed 19 August 2019]).

${ }^{35}$ See Art. 2 para. 1 lit. (g) of the Organic Law 2/1979 on the Constitutional Court of 3 October 1979 (English translation: www.tribunalconstitucional.es/es/tribunal/normativa/Normativa/LOTC-en. pdf [accessed 19 August 2019]).
} 
constitutional crisis could have been avoided or, at least, it would not have so escalated as it proved to be.

\section{Legal Effects of the K 34/15 Judgment}

During the debate on the constitutional crisis in Poland the argument was frequently raised that, as a result of the CT judgment of 3 December 2015 (ref. no. K 34/15), the Polish President became obliged to give the oath of office to three judges appointed by the previous Sejm. This judgment was also referred to as the justification of the CT President's refusal to assign cases to three judges elected by the new Parliament. In general, the aforementioned judgment is often understood as declaring the lawfulness of elections of three judges appointed by the previous Sejm. ${ }^{36}$ Some important questions should be, however, explained in a more detailed manner.

First of all, it should be explained that the K 34/15 judgment was announced already after the new Sejm had appointed five constitutional judges and the President had sworn four of them. Furthermore, the judgment concerned merely some legal provisions of the CT Act 2015. The Tribunal did not directly examine the Sejm's resolutions adopted within the constitutional judges' appointment procedure, since (as it was explained herein before) it was not constitutionally authorized to review such resolutions. Nonetheless, in the reasoning of the K 34/15 judgment, the Tribunal expressed a viewpoint that the previous Sejm had been empowered to elect, and actually had effectively elected, three judges who should have been sworn by the President, despite the fact that, a few hours before, the President had sworn judges elected by the new Parliament. ${ }^{37}$

It is undisputable that, under the rule of law principle, all state bodies should respect and implement the CT's judgments. Simultaneously, there are many doubts concerning the legal effects of these judgments. Pursuant to the Constitution, the CT's judgments are, in general, prospective and they do not automatically exert influence upon acts or decisions issued before a judgment's entry into force. ${ }^{38}$ For

\footnotetext{
${ }^{36} \mathrm{Cf}$., inter alia, the Venice Commission's Opinion no. 833/2015 (referred to in footnote 1), margin numbers 26, 124; the Commission Recommendation (EU) 2016/1374 (referred to in footnote 1), 8 . ${ }^{37}$ In the Tribunal's opinion: 'In the case of the two judges of the Tribunal whose terms of office either ended on 2.12 or will end on 8.12.2015, the legal basis of the significant stage of the judicial election process was challenged by the Tribunal as unconstitutional. (...) the derogation of the relevant scope of Art. 137 of the CT Act should result in the discontinuance and closure of the procedure (...). The completion of the aforementioned procedure is inadmissible (...). (..) what does not raise constitutional doubts is the legal basis of the election of the three judges of the Tribunal who were to take office after the judges whose terms of office had ended on 6.11.2015. The derogation of Art. 137 of the CT Act within the indicated scope does not affect the election of those judges. (...) the judicial election carried out on that basis was valid and there are no obstacles to complete the procedure by the oath of office taken, before the President of Poland, by the persons elected to the judicial offices in the Tribunal.'

${ }^{38}$ See Art. 190 para. $2-4$ of the Constitution.
} 
that reason, it is debatable whether, and in what manner, the $\mathrm{K} \mathrm{34/15}$ judgment affected the Sejm's resolutions of 8 October and 2 December 2015 on electing constitutional judges. It would be an oversimplification to argue that the said judgment nullified three out of five resolutions of the new Sejm (adopted on 2 December 2015) and definitively confirmed the legality of three out of five resolutions of the previous Sejm (adopted on 8 October 2015). The constitutional judges have been appointed directly on the basis of Art. 194 para. 1 of the Constitution, as opposed to the 2015 Act which only provided for certain procedural components of the appointment process.

According to the legal doctrine and courts' jurisprudence, including the jurisprudence of the CT, only the operative part of a CT judgment is legally binding within the meaning of Art. 190 para. 1 of the Constitution. ${ }^{39}$ Arguments or opinions expressed by the CT in the reasoning parts of its judgments are, on one hand, frequently respected and applied by courts and other state bodies but, on the other hand, they are not universally binding since the Constitution did not introduce such an obligation. Consequently, state bodies are not legally compelled to obey such directives in their activity. ${ }^{40}$ It is not unusual that a state body, e.g. a court, refuses to follow the CT's instructions contained within the reasoning part of a CT's judgment, in particular the instructions concerning the legal effects produced by the judgment. Therefore, ignoring certain considerations contained in the reasoning of a CT's judgment, including considerations concerning the legal effects of a judgment, may not be, in general, tantamount to the law violation.

It should also be noted that, as regards the participation of the Polish President in the appointment procedure (the swearing-in stage), the Tribunal issued a so-called interpretative judgment. ${ }^{41}$ Yet, the Tribunal's power to issue such judgments remains disputable and, for many years, it has been questioned in some courts' jurisprudence. In particular, in 2009, the Polish Supreme Court adopted a resolution in which it expressed an opinion that the Tribunal was not constitutionally empowered to declare, in a universally binding manner, which interpretation of a legal provision is constitutional and which violates the Constitution. ${ }^{42}$

The legal problem concerning the swearing-in stage is pivotal, since the Constitution fails to envisage any form of the Polish President's participation in the procedure of appointing constitutional judges. One may, therefore, pose a question why the Tribunal decided to resolve the aforementioned problem in the controversial form of an interpretative judgment. Should the Tribunal have quashed the whole

\footnotetext{
${ }^{39}$ 'Judgments of the Constitutional Tribunal shall be of universally binding application and shall be final.'

${ }^{40}$ See, in particular, the resolution of the Supreme Administrative Court of 10 January 2011, ref. no. I OPS 3/10.

${ }^{41}$ See point 5 of the K $34 / 15$ judgment's operative part: 'Art. 21 para. 1 of the Act (...), interpreted other than that the President of the Republic of Poland is obliged to give the oath of office forthwith to a judge of the CT who has been elected by the Sejm, is inconsistent with Art. 194 para. 1 of the Constitution.'

${ }^{42}$ See the resolution of the Supreme Court of 17 December 2009, ref. no. III PZP 2/09.
} 
provision concerning the swearing-in procedure, the legal effects of its judgment would have been, to that extent, less ambiguous. ${ }^{43}$

In consequence, the legal effects of the K 34/15 judgment remain vague. Perhaps the situation would have been different, should the law have expressly empowered the Tribunal to define the legal effects produced by its judgments and the way they should be implemented, like it is, for instance, in Germany. ${ }^{44}$ Maybe it would be also worthy of searching for some ideas in the Amendment of the Spanish Constitutional Court Act, concerning the enforcement of the Court's judgments. ${ }^{45}$

\section{May the Constitutional Tribunal Bypass an Act of Parliament?}

One of the most important stages of the constitutional crisis occurred when, on 9 March 2016, the majority of the Tribunal's judges decided to bypass some provisions of the Amendment Act of 22 December 2015, which entered into force on the day of its official publication, and to declare this Act's unconstitutionality (the K 47/15 judgment). As it was explained herein before, the judgment was passed by the 12-judge panel, despite the fact that, according to the Amendment Act which had already been in force, the plenary session of the Tribunal should have been composed of at least 13 judges. For that reason, the Prime Minister's Chancellery denied the official publishing of the judgment.

Some arguments that justified the constitutional judges' decision to bypass certain provisions of the binding Act of Parliament might have been found in Art. 195 para. 1 of the Constitution, according to which constitutional judges are subject only to the Constitution. ${ }^{46}$ A similar provision is contained in Article 178 para. 1 of the Constitution which stipulates that 'regular' judges (in particular, judges of common and administrative courts) are subject only to the Constitution and statutes (Acts of Parliament). The aforementioned provision is commonly understood in Polish legal doctrine and jurisprudence as empowering judges to bypass sub-statutory acts (inter alia, governmental regulations, referred to in Article 92 of the Constitution) which are, in a court's opinion, inconsistent with an Act of Parliament or with the Constitution. Accordingly, Article 195 para. 1 of the Constitution may be interpreted as granting judges of the CT the power to deny applying a sub-constitutional act, in

\footnotetext{
${ }^{43}$ See Wiącek (2016), pp. 125 et seq.

${ }^{44}$ See Art. 35 of the Act on the Federal Constitutional Court 1951.

${ }^{45}$ See Organic Law 15/2015 of 16 October 2015 on the reform of Organic Law 2/1979 of the Constitutional Court concerning the execution of decisions of the Constitutional Court as a guarantee of the rule of law (English translation: www.venice.coe.int/webforms/documents/ default aspx ?pdffile $=$ CDL-REF(2016)035-e [accessed 19 August 2019]).

${ }^{46}$ Cf. Radziewicz (2017), pp. 23 et seq.; Safjan (2016), pp. 35 et seq.
} 
particular an Act of Parliament, in the situation where according to the CT an act in question is unconstitutional.

There are, however, scholars and constitutional judges who express the opinion that the Tribunal should obey even constitutionally questionable procedural norms, since-until ruling upon their inconformity with the Constitution-these norms enjoy the presumption of constitutionality. Furthermore, on one hand, pursuant to Article 195 para. 1 of the Constitution, constitutional judges are bound only by the Constitution but, on the other hand, the Constitution itself, in Art. 197, stipulates that the mode of proceedings before the Tribunal shall be regulated by the Act of Parliament. $^{47}$

Perhaps the situation would be different, if acts concerning the mode of proceedings before the Tribunal were under obligatory constitutional review prior to their entry into force, like it is, for instance, in France. ${ }^{48}$ Such a provision would make it possible to avoid the paradox situation where the Tribunal would be obliged to proceed on the basis of an Act which already came into force and, at the same time, is under constitutional review.

Furthermore, the constitutional crisis in Poland could have proved to be less escalated, if the law explicitly stated that the Tribunal may refuse to apply provisions that it deems unconstitutional, like it is in Lithuania. Art. 17 sentence 2 of the Lithuanian Constitutional Court Act 1993 stipulates that the Constitutional Court shall obey the Constitution and only such laws that are not inconsistent with the Constitution.

\section{Presumption of Legality of Acts Issued by State Bodies}

In the debate concerning the constitutional crisis in Poland, another fundamental question arose, namely whether a Tribunal's judgment may be found, by another organ of public power-e.g. by the Prime Minister (whose duty is to officially publish the Tribunal's judgments) or by a court (whose duty is to apply the Tribunal's judgments in individual cases)_-illegal and non-existent due to controversies concerning the composition of a Tribunal's panel that adjudicated a particular case.

In my opinion, the answer to that question is 'no'. Neither the Constitution nor the legislation vest any state body with the power to evaluate the lawfulness of the Tribunal's judgments - in particular, with the power to declare that a judgment was delivered by the unlawfully-composed panel and thus was illegal or non-existent. From the moment when a judgment is ordered to be published by the CT President and referred to the Prime Minister's Chancellery, it should be presumed legal, then

\footnotetext{
${ }^{47}$ See, in particular, the dissenting opinions of judges J. Przyłębska and P. Pszczółkowski attached to the K 47/15 judgment (referred to in footnote 18). Cf. Zubik (2011), p. 116.

${ }^{48}$ It stems from Art. 61, read in conjunction with Art. 63, of the French Constitution 1958.
} 
officially published and respected by individuals and all state bodies, in particular courts. It is the CT President's legal responsibility that an act sent for publication is indeed a legally-delivered Tribunal's judgment. That act enjoys the presumption of legality.

Nonetheless, I am of the opinion that the Parliament would be empowered to introduce a procedure under which, in certain exceptional circumstances, the Tribunal's judgments might be challenged. In particular, the current Polish legislation makes it possible to nullify a final court judgment issued by the wrongfullycomposed judicial panel. ${ }^{49}$ There are no constitutional obstacles against introducing such an extraordinary procedure when it comes to the Tribunal's judgments. Not only a final court decision but also a judgment delivered by the CT may be, hypothetically, burdened with such procedural defects that may justify the nullification of a judgment and re-considering a particular case. ${ }^{50}$ It should be emphasized that there are some states in Europe where the proceedings before constitutional courts may be, in certain circumstances, re-opened what, in consequence, may lead to the re-examination of a case which was already settled by a final judgment. ${ }^{51}$

\section{Closing Remarks. The Crisis of Procedures}

The constitutional crisis in Poland is, to some extent, the crisis of procedures. There are some crucial constitutional issues which are not reviewable and, therefore, some pivotal constitutional disputes may remain unsettled by the judiciary. In particular, the authors of the Constitution failed to anticipate that the appointment of a constitutional judge may be subject to legal controversies and they failed to provide for procedures that could lead to the definite resolving of such controversies by an impartial organ of the judiciary. A constitution of a state governed by the rule of law should provide for, one may call it, 'fail-safe procedures', guaranteeing the respect for the principle of legality. The constitutional crisis proved that the Polish Constitution is not sufficiently consistent with this standard. As it turned out, the political will of the majority of Parliament was capable to break the hitherto established

\footnotetext{
${ }^{49}$ See, in particular, Art. 401 para. 1 of the Civil Procedure Code 1964; Art. 542 para. 3, read in conjunction with Art. 439 para. 1 subpara. 1-2, of the Criminal Procedure Code 1997; Art. 271 para. 1 of the Act on the Proceedings before Administrative Courts 2002.

${ }^{50}$ For instance, one of the judges sitting in the Tribunal's panel which pronounced the judgment of 2 April 2003 (ref. no. K 13/02) had been previously a Senator and had voted on the provision that was under review in this case. The Tribunal, however, decided that there was no basis for the re-opening of procedure (see the decision of 17 July 2003, ref. no. K 13/02, English summary: www.trybunal.gov.pl/fileadmin/content/omowienia/K_13_02_GB.pdf [accessed 19 August 2019]; see also Tuleja (2014), pp. 62 et seq.

${ }^{51}$ See, in particular, Art. 119-119b of the Czech Republic Constitutional Court Act 1993; Art. 75-75b of the Slovakian Constitutional Court Act 1993; Art. 62 of the Lithuanian Constitutional Court Act 1993.
} 
practice in electing the CT judges and there was no legal remedy to be filed directly against these decisions.

In particular, the question of legality of electing three judges by the previous Sejm remains controversial and debatable, since no organ of judicial power is vested with the power to finally adjudicate upon that question in a binding manner. As it was explained herein before, the legal effects of the $\mathrm{K} 34 / 15$ judgment are unclear. Simultaneously, the Sejm's resolutions on electing judges may not be reviewed by the Tribunal, what was confirmed by the Tribunal in the U 8/15 decision. Hence, on one hand, one may raise arguments, based on the CT's stance, expressed in the reasoning parts of judgments delivered in 2015 and 2016, that the previous Sejm was empowered to appoint three constitutional judges who, subsequently, should have been sworn by the Polish President. On the other hand, it should be noticed that the thesis that the previous Sejm was authorized to elect three judges is founded on the assumption that three vacancies at the CT undoubtedly opened in the course of the previous Sejm's term of office (i.e. on 7 November 2015). Such an assumption has basis in facts, the calendar of these facts was, however, unknown on the day when the previous Sejm appointed judges. In other words, on 8 October 2015 it was uncertain whether the previous Sejm's term of office would encompass the day when three vacancies at the Tribunal would open. ${ }^{52}$ A question whether this argument, overlooked in the CT's judgments, influenced-in the light of the tempus regit actum principle-upon the legality of elections, performed by the previous Sejm, remains open.

Under the rule of law principle, all state bodies should mutually respect their acts and decisions. It means that, except for certain extraordinary and evident situations, a state body should not treat acts or decisions issued by another state body as invalid or non-existent, unless it is declared within a procedure prescribed by the law. Otherwise, a legal chaos may occur, what would be per se contrary to the rule of law principle. In particular, in the current system of law the Prime Minister's Chancellery is not vested with the power to deny publishing a CT's judgment in the situation where it was properly sent for publication on the basis of the CT President's order. For the same reasons, Polish courts are not empowered to evaluate the lawfulness of CT's judgments, including the situation where a court raises doubts as regards the composition of a particular Tribunal's adjudicating panel. Such a conclusion flows from the fact that one of the crucial elements of the rule of law principle is the certainty of law. Notwithstanding the legal controversies concerning the current composition of the Tribunal, its judgments should be published, respected and

\footnotetext{
${ }^{52}$ In the light of Art. 98 para. 1 and Art. 109 para. 2 of the Constitution (see footnote 10) the Sejm's term of office is, to some extent, flexible. The exact date of the inauguration of new Sejm's term of office had been unknown until 5 November 2015, when the President summoned the first sitting of the new Sejm and set its date for 12 November 2015. Theoretically, the new Sejm could have inaugurated its term of office even one day after parliamentary elections, on 26 October 2015. It was, therefore, conditional upon the decision of the Polish President. Cf. Brzozowski (2016), p. 149.
} 
applied by courts and other state bodies. The protection of the principle of legality may not lead to the negation of the principle of law certainty.

\section{References}

Bárd P (2016) Scrutiny over the rule of law in the European Union. Polish Yearb Int Law 36:187-208

Brzozowski W (2016) Niezależność konstytucyjnego organu państwa i jej ochrona [Independence of a constitutional state body and its protection]. Wydawnictwo Sejmowe, Warsaw

Brzozowski W (2017) O potrzebie reformy konstytucyjnej [On the need for a constitutional reform]. Państwo i Prawo 12:3-22

Krzywoń A (2018) La crisis constitucional en Polonia (2015-2017): cómo cuestionar el sistema del equilibrio constitucional en dos años. Teoría y Realidad Constitucional 41:359-379

Kustra A (2016) Poland's constitutional crisis. From court-packing agenda to denial of Constitutional Court's judgments. Toruńskie Studia Polsko-Włoskie - Studi Polacco-Italiani di Toruń XII:343-366

Muszyński M (2017) Legal analysis of the election process of the judges of the Polish Constitutional Tribunal in the autumn of 2015. Iustum Aequum Salutare XIII(1):127-143

Radziewicz P (2017) Refusal of the Polish Constitutional tribunal to apply the act stipulating the constitutional review procedure. Rev Comp Law 1(28):23-40

Sadurski W (2019) Poland's constitutional breakdown. Oxford University Press, Oxford

Safjan M (2016) Politics and the constitutional tribunal. The constitution - the last instrument of defence against politics. Ruch Prawniczy, Ekonomiczny i Socjologiczny 1(78):35-42

Szuleka M, Wolny M, Szwed M (2016) The constitutional crisis in Poland 2015-2016. https:// www.hfhr.pl/wp-content/uploads/2016/09/HFHR_The-constitutional-crisis-in-Poland-20152016.pdf. Accessed 19 Aug 2019

Taborowski M (2019) Mechanizmy ochrony praworządności państw członkowskich w prawie Unii Europejskiej. Studium przebudzenia systemu ponadnarodowego [The European Union law's mechanisms for protecting the rule of law in the Member States: a study on the awakening of the supranational systemta]. Wolters Kluwer, Warsaw

Tuleja P (2014) Proceedings before the Constitutional Court in relation to the Hierarchical Review of Norms. Sejm Rev:47-64. Fifth Special Edition

Wiaccek M (2007) A review of the principal reasons for selected judicial decisions issued by the Constitutional Tribunal in the years 1997-2006. Sejm Rev:165-199. Third Special Edition

Wiącek M (2016) Commentary to the judgment of the Constitutional Tribunal of 3.12.2015 (ref. no. K 34/15). Przegląd Sejmowy 2(133):124-132

Zubik M (2011) Status prawny sędziego Trybunału Konstytucyjnego [The legal status of the judge of the constitutional tribunal]. Wydawnictwo Sejmowe, Warsaw

Marcin Wiącek is a professor of the Faculty of Law and Administration at the University of Warsaw; the Head of the Human Rights Division. 
Open Access This chapter is licensed under the terms of the Creative Commons Attribution 4.0 International License (http://creativecommons.org/licenses/by/4.0/), which permits use, sharing, adaptation, distribution and reproduction in any medium or format, as long as you give appropriate credit to the original author(s) and the source, provide a link to the Creative Commons license and indicate if changes were made.

The images or other third party material in this chapter are included in the chapter's Creative Commons license, unless indicated otherwise in a credit line to the material. If material is not included in the chapter's Creative Commons license and your intended use is not permitted by statutory regulation or exceeds the permitted use, you will need to obtain permission directly from the copyright holder. 